\title{
A new species of the genus Panstrongylus from French Guiana (Heteroptera; Reduviidae; Triatominae)
}

\author{
Jean-Michel Bérenger, Denis Blanchet*
}

Unité d'Entomologie Médicale, Département d'Epidémiologie et de Santé Publique, IMTSSA, BP 46 Le Pharo, F-13998 MarseilleArmées, France *Service hospitalier universitaire de parasitologie et mycologie, Equipe EA 3593, C. H. de Cayenne,

\author{
Cayenne Cedex, Guyane française
}

Panstrongylus mitarakaensis $n$. sp. is described from French Guiana. Morphological characters are provided. This small species, less robust than other Panstrongylus species, shows a pronotum shape similar to species of the "P. lignarius complex". However, others characters such as the postocular part of head, the obsolete tubercle on the anterior lobe of pronotum, and the lateral process on the antenniferous tubercle distinguish it from the species in that complex. The taxonomic key of the genus Panstrongylus is actualized.

Keys words: Triatominae - Panstrongylus mitarakaensis n. sp. - French Guiana

The genus Panstrongylus comprises 13 species distributed from Argentina to Nicaragua (Lent \& Wygodzinsky 1979, Jurberg et al. 2001, Marcilla et al. 2002, Galvão et al. 2003, Jurberg \& Galvão 2006). The 14 th species of the genus, which we describe in the following, was collected by JP Champenois (entomologist) during an expedition to the border of French Guiana with Brazil at the top of a granite outcrop where the boundary stone number one is situated, in the southeast of the Mitaraka Mountains. This Caribbean granite outcrop $(592 \mathrm{~m})$ constitutes an open area in the primary rainforest. It is the only Triatominae collected at this site.

The pronotum of this new species resembles in shape those observed in $P$. lignarius and $P$. humeralis, the two species forming the "Panstrongylus lignarius complex" (Carcavallo et al. 1999, 2000).

\section{MATERIALS AND METHODS}

The genitalia were examined in glycerol after $\mathrm{KOH}$ treatment. For the research of Trypanosoma, a part of the rectal ampoule content from the specimen was mixed with physiological saline and examined under a light microscope using a $400 \mathrm{X}$ magnification to find presence of parasites. In parallel $2 \mu$ of the sample were fixed on a glass slide, stained with May-Grünwald Giemsa, and observed at $1000 \mathrm{X}$ magnification, to appreciate precisely the morphology of the trypanosomes. Another part of rectal ampoule content was mixed with deionised water and stored in cryotubes at $-80^{\circ} \mathrm{C}$ for further molecular analyses.

A middle leg of the holotype was cut off and has been preserved in alcohol $70^{\circ}$ for future genetic studies.

The specimen was collected with a light trap composed of a vertically disposed white sheet, lighted with two $250 \mathrm{~W}$ mercury-vapour lamps.

E-mails: jmberenger@free.fr, d.blanchet@ laposte.net Received 9 March 2007

Accepted 16 July 2007
Material examined: male holotype: French Guiana, location boundary stone $1,02^{\circ} 12^{\prime} 505^{\prime \prime} \mathrm{N}, 54^{\circ} 26^{\prime} 315 \mathrm{~W}$, 20.IX.2006, Light trap, JP Champenois leg (in Department of Hemiptera, Museum national d'Histoire naturelle, Paris, France). All measures are in $\mathrm{mm}$.

Panstrongylus mitarakaensis, n. sp.

Description of the male (Fig. 1). Length: $21 \mathrm{~mm}$.

General colour light brown; margin of ocelli, irregular spots on anterior lobe and posterior margin of pronotum, veins in middle and apex of corium, median area and veins of membrane, rectangular and rounded spots on the connexiva of segments II to VII, dark brown to black.

Head - (Fig. 3A, B) total length = 3.0; anteocular part $=1.56$; postocular part $=0.62$. Light brown with dorsal surface slightly granulose, with short refringent setae, and two inconspicuous black stripes; anteocular part with transverse stria in front of eyes; sides of postocular part almost straight; ventral surface blackish; antenniferous tubercles with apicolateral process; first antennal segment light brown, remaining segments (II to IV) blackish; ratio of antennal segments: $0.4: 1: 0.8$ : 0.8. Postocular part with small tubercles laterally; eyes in lateral view extending beyond ventral surface; Synthlipsis $=0.68$; ocelli not elevated, with broad black stripe joined on neck forming a Y; rostrum brown; ratio of rostral segments: $0.7: 1.0: 0.3$.

Neck smooth.

Thorax - Pronotum light brown; total length $=3.0$; width of anterior lobe $=2.31$, width of posterior lobe $=$ 4.75. Tubercles of collar projecting and rounded, with black spot. Anterior lobe rectangular, divided by a longitudinal furrow, deeper posteriorly with a rectangular black spot; each part anterior and laterally bordered by a tubercle; surface irregular, with two conspicuous and several more inconspicuous black spots. Lateral margins blackish.

Posterior lobe irregularly rugose, larger than anterior lobe; $1+1$ carinae reaching middle of disc on each side of median depression; humeral angle flattened and slightly raised; posterior margin smooth with blackish suffusion. 


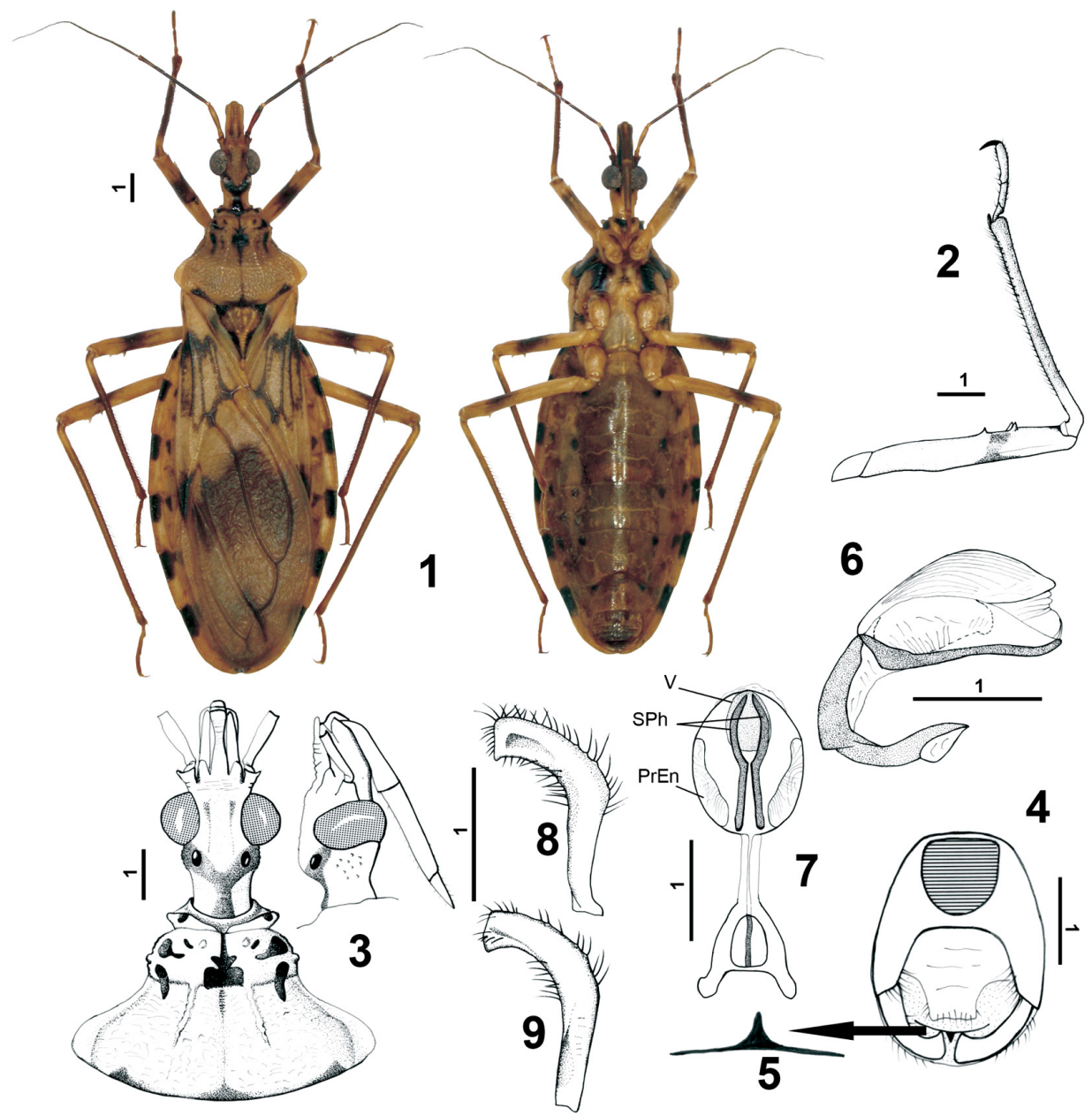

Figs 1-9: Panstrongylus mitarakaensis n. sp. 1: habitus holotype male dorsal and ventral view; 2: anterior leg; 3 : detail of head and pronotum dorsal view and head lateral view; 4: pygophore upper view; 5: detail of pygophore process; 6: phallus, lateral view; 7: phallus, ventral view; (V: vesica; SPh: phallosoma support; PrEn: endosoma processes). 8: right paramere. 9: left paramere (Bar $=1 \mathrm{~mm})$.

Scutellum rugose and tomentose; black with disc light brown; disc with two carinae in $\mathrm{V}$ shape; process long, irregular, and with transverse ridges, apex rounded.

Hemelytra - Clavus light brown with a median blackish spot on basal third; corium light brown with median veins and apex blackish. Membrane light brown, a median brown patch extending into internal and external cells; veins generally brown to black; membrane almost reaching posterior border of abdomen.

Legs - Tibiae brown with light brown base; ventral surface with strong setae. Femora light brown with an irregular brown annulus, in apical third. Profemora with three spines on ventral face; two spines on meso- and metafemora. Tarsi brown, segment I shortest, II and III of subequal length; pro- and mesotibia with very small fossula spongiosa.

Abdomen - Broad, oval, maximal width $=6.75$. Colour light brown. Connexivum light brown, with blackish rectangular mark on each segment. Venter uniformly light brown with two black spot on each sternite (Fig. 2).

Genitalia - Posterior border of pygophore regular (Fig. 4), internal rim with a spiniform process (Fig. 5). Parameres curved, L-shaped with strong erect setae variable in length on outer and inner sides (Figs 8, 9). Dorsal phallothecal plate large and oval. Basal half of the supports of phallosoma straight and apical half curved; struts not connected at their apices. Lateral endosoma processes cylindrical, their apices narrowed and curved in lateral view (Fig. 6). Pedicel long and narrow. Dorsal face of phallosoma longitudinally striated (Fig. 6).

Female unknown.

Etymology - The specific epithet name mitarakaensis refers to the Mitaraka mountains in the vicinity of which this new species has been collected.

Biology - The single known specimen was kept in captivity in a plastic flask with a compress soaked with honey and water for one month. No blood has been pro- 
vided. It showed great activity compared to other species of the same genus, as $P$. geniculatus. The content of the posterior portion of the intestine was light brown, very fluid, with numerous epimastigote and trypomastigote metacyclic forms of Trypanosoma, morphologically identical to those of $T$. cruzi.

\section{DISCUSSION}

P. mitarakaensis $\mathrm{n}$. $\mathrm{sp}$. is recognized among other species of Panstrongylus by its body less robust and smaller $(21 \mathrm{~mm})$ than the one in most other Panstrongylus species with the exception of P. lenti $(19 \mathrm{~mm})$, by all femora furnished with a black irregular annulus and by an apicolateral process on the antenniferous tubercle, a character found only in a sympatric species, $P$. geniculatus; it resembles this species by its coloration of pronotum and the elongate postocular part of head, but is clearly distinguished by the shape of the pronotum. This pronotum is remarkable by its lateral margins parallel on the anterior lobe and a large posterior lobe possessing flattened humeral angle, a character that is only shared with species of the "P. lignarius complex" This complex currently comprises the species $P$. lignarius, another sympatric Panstrongylus, and $P$. humeralis (Hypša et al. 2002, Marcilla et al. 2002, Santos et al. 2003). In addition, the coloration of $P$. mitarakaensis n. sp. resembles the one of these two species. However, $P$. mitarakaensis $\mathrm{n}$. sp. can be distinguished from these two species by its body less robust, by a long postocular part of head, by the presence of only two obsolete tubercles on the anterior pronotal disc and by a posterior process of scutellum long and thin, some characters sufficient for us, and for the moment, to remove P. mitarakaensis n. sp. from this complex.

Future molecular phylogenetic analysis will shed light on the possible affinity of P. mitarakaensis $\mathrm{n}$. $\mathrm{sp}$. to the "P. lignarius complex".

Since the revision of the subfamily Triatominae by Lent and Wygodzinsky (1979), two new species have been added to the genus Panstrongylus. Furthermore many studies have proved, using molecular and morphological data (Marcilla et al. 2002, Santos et al. 2003), that $P$. lignarius and $P$. herreri are a same species. This synonymy is adopted by Galvão et al. (2003) and we follow these authors in this view. So we propose to actualize the 1979'key of the genus Panstrongylus.

Updated key of the genus Panstrongylus after Lent and Wygodzinsky (1979):

1. Process of scutellum elongate subcylindrical, narrowed apicaly

Process of scutellum short, rounded, conical or truncate apically ... 11

2. Specimens almost completely black; small red spot on posterolateral angle of connexivum segments and, in some cases, reddish markings on the pronotum ...... chinai

Specimens differently colored ............................ 3

3. Length less than $20 \mathrm{~mm}$; fore lobe of pronotum light brown immaculate ........................................ lenti

Length more than $20 \mathrm{~mm}$; fore lobe of pronotum with dark markings ..................................................... 4
4. Abdomen light colored ventrally, with longitudinal series of black spots ................................... 5

Abdomen differently colored, without series of black

spots ..................................................... 6

5. Pronotum with humeral angles flattened; femora light brown with a median black annuli ....... mitarakaensis

Pronotum with humeral angles rounded; femora black with apex reddish .......................................... geniculatus

6. Rostrum with second segment as long as or shorter than first .............................................. tupynambai

Rostrum with second segment invariably longer than first ........................................................ 7

7. Corium yellow except at extreme base and subapically, strongly contrasting with dark gray membrane; synthlipsis much less than twice as large as width of eyes in dorsal view; femora with slight subapical protuberances ............................................... howardi

Corium as dark as membrane, with base and apex lighter colored; synthlipsis twice or more than twice as large as width of eyes in dorsal view; fore and mid femora with several conspicuous denticles ....................... 8

8 . Fore lobe of pronotum with distinct discal tubercules ............................................ 9

Fore lobe of pronotum with only obsolete or without discal tubercles ......................................... 10

9. Anteocular region of head 2,5 times as long as postocular region; overall colour brownish/black with small light markings ........................................... sherlocki

Anteocular region of head two times as long as postocular region; overall colour yellowish brown with dark brown markings in particular on pronotum, corium and connexivum lutzi

10. Anterolateral processes of pronotum very short, blunt; upper surface of head straight; fore and mid femora with 2 or 3 denticles; lateral borders of pronotum lobes forming a continuous line diasi

Anterolateral processes of pronotum long and salient; upper surface of head convex; fore and mid femora with more than 3 denticles; lateral borders of pronotum lobes forming a distinct angle guentheri

11. Jugae blunt; tubercles of fore lobe of pronotum reddish; connexival segments with central dark spot; body dorsally with golden setae; hemelytra pale green ....... rufotuberculatus

Jugae with hook-like projection; tubercles of fore lobe of pronotum not or rarely reddish; connexival segments with anterior dark spot; body dorsally practically glabrous; hemelytra not green .................................... 12

12. Overall colour black with red markings, four on the hind lobe of pronotum; third antennal segment shorter than the second ................................................. megistus

Overall colour yellowish to yellowish brown with dark markings; hind lobe of pronotum with one median and $2+2$ longitudinal dark markings; third antennal segment as long as second ......................................... 13

13. Scutellun yellowish with a median longitudinal stripe black; fore lobe of pronotum without sublateral tubercles humeralis 
Scutellun black with a median longitudinal stripe yellow; fore lobe of pronotum with sublateral tubercles lignarius

\section{ACKNOWLEDGEMENTS}

To J-P Champenois for the donation of the single specimen of $P$. mitarakaensis and to the association "Alabama" (French Guiana) in charge of this expedition. For their collaboration, to Dr F Pages (IMTSSA, France) and Dr G Egman (SAMU Guyane). To Dr C Aznar who have, since ten years, greatly contributed to the study, the prevention and, in general, the knowledge of Chagas disease in French Guiana. To C Weirauch (University of California) and H Gil-Santana (Instituto Oswaldo Cruz, Brazil) for the reviews and the suggestions.

\section{REFERENCES}

Carcavallo RU, Jurberg J, Lent H 1999. Phylogeny of the Triatominae. A - General approach. In RU Carcavallo, I Galindez Girón, J Jurberg, H Lent, Atlas of Chagas' Disease Vectors in the Americas, Fiocruz, Rio de Janeiro, p. 925-939.

Carcavallo RU, Jurberg J, Lent H, Noireau F, Galvão C 2000. Phylogeny of the Triatominae (Hemiptera: Reduviidae). Proposals for taxonomic arrangements. Entomol Vect 7 (Suppl. 1): 1-99.

Galvão C, Carcavallo RU, Rocha DS, Jurberg J 2003. A checklist of the current valid species of the subfamily Triatominae Jeannel, 1919 (Hemiptera, Reduviidae) and their geographi- cal distribution, with nomenclatural and taxonomic notes. Zootaxa 202: 1-36.

Hypša V, Tietz DF, Zrzavý J, Rego ROM, Galvão C, Jurberg J 2002. Phylogeny and biogeography of Triatominae (Hemiptera : Reduviidae): molecular evidence of a New World origin of the Asiatic clade. Mol Phylogenet Evol 23: 447-457.

Jurberg J, Galvão C 2006. Biology, ecology, and systematics of Triatominae (Heteroptera, Reduviidae), vectors of Chagas disease, and implications for human health. Festschrift zum 70. Geburtstag von Ernst Heiss. Denisia 19, zugleich Katalogue der OÖ. Landesmuseen Neue Serie 50. Linz: v. 19, p. 1095-1116.

Jurberg J, Carcavallo RU, Lent H 2001. Panstrongylus sherlocki sp. n. do estado da Bahia, Brasil (Hemiptera, Reduviidae, Triatominae). Entomol Vect 8: 261-274.

Lent H, Wygodzinsky P 1979. Revision of the Triatominae (Hemiptera, Reduviidae), and their significance as vectors of Chagas' disease. Bull Amer Mus Nat Hist 163: 123-520.

Marcilla A, Bargues MD, Abad-Franch F, Panzera F, Carcavallo RU, Noireau F, Galvão C, Miles M, Dujardin JP, Mas-Coma S 2002. Nuclear rDNA IST-2 sequences reveal polyphyly of Panstrongylus species (Hemiptera: Reduviidae: Triatominae), vectors of Trypanosoma cruzi. Infect Gen Evol 1: 225-235.

Santos CM, Jurberg J, Galvão C, Rocha DS , Fernandez JIR 2003. Estudo morfométrico do gênero Panstrongylus Berg, 1879 (Hemiptera, Reduviidae, Triatominae). Mem Inst Oswaldo Cruz 98: 939-944. 